\title{
Security Problems in College and University Libraries: Student Violence
}

\begin{abstract}
A survey of the news media and library literature was made to determine the extent of student violence and its impact on academic libraries. Findings show that campus disorders are increasing and present a heavy financial burden. Although there have been only scattered incidents of arson and vandalism in academic libraries, the number of such incidents has increased recently. Specific incidents are discussed with suggestions on how security may be improved.
\end{abstract}

$\mathbf{P}$ rotecting College and university libraries is an exceedingly complex problem. Academic libraries are vulnerable to sit-ins, fire, bombings, book thefts, vandalism, natural disasters, including earthquakes and floods, burglaries, and other threats to safety. The most serious current problem in the security of academic libraries is student violence.

At the start of 1970, it appeared that the five years of student violence in the United States had begun to abate. ${ }^{1}$ The 1968/69 academic year had been the most violent ever, according to the Federal Bureau of Investigation. There had been 61 incidents of arson or bombing, and 4,000 arrests in conjunction with student disturbances. ${ }^{2}$ Total damage to college and university facilities was reported to be at least three million dollars. ${ }^{3}$ However, through December 31 of the 1969/70 school year, only 18 inci-

At the time this article was written, Miss Davis was a student at the Graduate School of Librarianship, University of Southern California. dents of arson or bombing, and about 350 arrests were reported. ${ }^{4}$

Events of the first few months of 1970 dramatically reversed this trend. According to the Urban Research Council, a private group which has researched campus demonstrations for the last two years, 92 incidents of student protest took place between mid-January and March 13, 1970, whereas only 88 occurred during the same period in $1969 .{ }^{5}$ In March, two incidents in New York also underscored the threat of terrorist bombings on campus. First, bombs which were intended for Columbia University were accidentally detonated, completely destroying a New York townhouse occupied by several leaders of the anarchist Weathermen faction of the Students for a Democratic Society. ${ }^{6}$ A few days later, two black activist college students were also inadvertently blown up by their homemade bomb cache. $^{7}$

The widespread student reaction in May to the student deaths at Kent State University proved again that student violence can be a dangerous and expen- 
sive force. Stanford University, for example, calculated that its expenses due to student disorders over a six-week period last spring exceeded half a million dollars. $^{8}$

A questionnaire was distributed in June 1969 by the Office of Research of the American Council on Education to a group of 427 selected colleges and universities in the United States. Response from 382 institutions implied that approximately 6.2 percent of all the colleges and universities in the United States had experienced violent protest in the $1968 / 69$ academic year. Furthermore, an additional 16.2 percent had experienced nonviolent disruption. The researchers concluded: "While these findings make clear that violence and disruption are not, as many press reports suggest, characteristic of most college campuses, they indicate also that the number of colleges that have experienced disorder is not inconsequential."

A recent book on student militance is titled Is the Library Burning?, but a short survey of damage in academic libraries in the past three years indicates that press reports have inflated the number of incidents, and only a few libraries have experienced arson. ${ }^{10}$ Within the last eighteen months, however, such incidents have increased strikingly and show considerable premeditation on the part of the instigators. The vandals and arsonists are seldom found, so that only a few of the following incidents can be attributed definitely to students. Nonetheless, these incidents show very well the vulnerability of the academic library.

In 1967 an arsonist ignited a blaze in the Wayne State University Library in Detroit, destroying 8,000 volumes and the entire order file. ${ }^{11}$ The student strike at Columbia University in 1968 caused minor damage to the Mathematics Library. ${ }^{12}$ In 1969 , the Indiana University Library was twice hit by fire. On Feb- ruary 17,1969 , about $\$ 500,000$ damage was caused when a fire in the subbasement spread through ventilating ducts to the two floors above. ${ }^{13}$ Several hundred reference works as well as 3,811 volumes of domestic and foreign newspapers, some of which were unique sets in the country, were totally destroyed; an additional 30,000 volumes were so damaged as to warrant replacement. ${ }^{14}$ On May 1, 1969, around 40,000 additional volumes were destroyed and 20,000 damaged. Over 50 percent of the German collection had been ruined. ${ }^{15}$

Last year, black student protests hit several campuses. At Brandeis University, books were disarranged in a minor incident, but no physical damage was done. ${ }^{16}$ At Queens College, according to head librarian Morris A. Gelfand, around twenty-five catalog drawers were destroyed or damaged. ${ }^{17} \mathrm{~A}$ much more serious incident took place at the University of Illinois where unknown vandals entered the library and removed approximately 16,000 cards from the public catalog. ${ }^{18}$ The cards were torn, burned, or disposed of in various waste receptables throughout the campus. Restoring the catalog involved identifying exactly which cards were missing and then trying to re-create exactly the information recorded on the cards. The process was extremely costly and time-consuming, as the nearly six million remaining cards had to be checked against Library of Congress information, the shelflist, and the actual books on the shelves.

At San Francisco State College, students paralyzed the library by overloading the circulation system. ${ }^{19}$ Vandals struck Beloit College, stealing equipment and slashing furniture. ${ }^{20}$ New York University suffered two separate arson incidents. First, a Molotov cocktail caused extensive damage to the Gould Memorial Library. ${ }^{21} \mathrm{~A}$ few days later, several small fires set in the Sage Engi- 
neering Library destroyed many technical microfilms. Approximately 30,000 cards from the catalog had been scattered and mutilated. ${ }^{22}$ At the University of Washington, a bomb gutted the interior of the administration building, causing over $\$ 100,000$ of damage, mostly through broken glass, to the adjacent Suzzallo Library. ${ }^{23}$

A more detailed account of how the library was affected at San Francisco State College will illustrate the variety of security problems which might confront the academic librarian during a typical demonstration. ${ }^{24}$ According to Barbara Anderson, the Education Librarian at San Francisco State, the first tactics were fairly mild: "Students were shoved out of their seats as they studied ... small fires were set in restrooms ... a few windows were broken." The library, because of its central location and multistory construction, became the "choice vantage point for demonstration watching." Thus, tight security was impossible as the building became filled with police, students, newsmen, and television crews. Moreover, the noise from the demonstration made work virtually impossible.

The "gradual forays of harassment" included bomb threats, "book-ins," cherry bombs, and stink bombs. The bomb threats were dismissed lightly until a real bomb was found on campus. From then on, campus security officers and librarians took on the enormous task of combing through the stacks, wastebaskets, and other possible bomb caches every time a threat was received.

"Book-ins" describe the practice of removing volumes from the shelves and scattering them randomly throughout the building. The disruptions in service were compounded by the fact that most of the student shelvers had joined the strike. Miss Anderson adds, "As you might expect, after four months with almost no shelvers, combined with mas- sive harassment, we had books stacked all over the floors and all over the tables. It was impossible to track down a particular title." Volunteers from the community came in to help with the shelving problem, but they had to cross picket lines and endure the obscenities shouted at them by the strikers.

The stink bomb problem was more formidable than it sounds. Not really bombs, but actually laboratory bottles filled with a nauseous liquid, the stink bombs were brought into the building in brown paper bags. Once the bottles were opened, some of the liquid was poured on the floor while the bottle and lid were hidden. Librarians were left with the extremely difficult and unpleasant task of searching them out. The Education Librarian continues:

The smell was so vile that for all practical purposes library work in the chosen areas came to a halt ... I might add, that scrub as we might, the liquid did not wash off the floors with soap and water; it lingered on for months afterwards. In some areas we can still smell it.

Cherry bombs were equally harassing. Left at random in the stacks, the noise from the fireworks completely disrupted work and frightened patrons into thinking real bombs had exploded. Moreover, the safety of staff and patrons was endangered by those bombs that did not explode. Removing a defective cherry bomb involved the risk that one's hand might be injured or even blown off.

One of the more serious problems came when the students decided to attack the catalog:

One day glue was found in a few card trays, another day, handfuls of catalog cards were found in the sink in a women's restroom. The Hayakawa entries had been removed one day. Some cards were found in a women's restroom in the Administration Building wrapped in paper with the message "On Strike, Shut It Down." 


\section{8 / College \& Research Libraries • January 1971}

Minor incidents continued throughout the strike; these included fires, clogged toilets, and paint sprayed on the walls in the restrooms, as well as numerous broken windows and vandalism in and outside the building.

During 1970, attacks on libraries have included the fire bombing of the Columbia University International Law Library and the setting of a fire in the Doe Memorial Library at the University of California, Berkeley. ${ }^{25}$ The Berkeley fire was deliberately ignited with gasoline and caused an estimated $\$ 320,000$ damage. ${ }^{26}$ Six people were injured, and two large reading rooms were destroyed. While no books were burned, Dr. James E. Skipper, University Librarian, reported that smoke and water damage would affect parts of the collection. ${ }^{27}$

Specialized research libraries were destroyed when the Black Studies Center at Cornell and the Center for Advanced Study in the Behavioral Sciences at Stanford were gutted recently by fire. ${ }^{28}$ Student rioting at the State University of New York at Buffalo resulted in the defacement of the library's exterior and in fire bombings inside the library. ${ }^{29}$ In March, during demonstrations by the Black Students Union at the University of Washington, incendiary devices were placed in the stacks, circulation files were damaged, and books were thrown off the shelves. ${ }^{30}$ At Yale in April, arson in the library of the Law School destroyed \$2,500 worth of books and property. ${ }^{31}$

Ironically, the library may also be the target of a conservative antistudent backlash. For example, the New York Public Library was struck by two bombs in its main reading room. The bomber evidently felt the library had sponsored or endorsed students who had participated in the October 15 Moratorium Day rally behind the library in Bryant Park. $^{32}$

It is obvious that security is a serious problem; most methods of combating violence are likely to be ineffectual. Still, some of the bitter lessons learned by librarians may help others to decrease the destruction. Librarians should be attuned to the prevailing student mood on campus. The librarian who is aware of militant factions cannot ignore them. Familiarizing oneself with studies on unrest should also give some clues as to whether the campus is likely to experience violence. For instance, the American Council on Education's study noted that violence was most prevalent in the large, highly selective university or four-year college. ${ }^{33}$ Moreover, at the university level more than one-third of the private universities experienced violence, whereas only one in eight public universities had comparable violence.

Bombs constitute a special threat. Several New York companies, including IBM, which were hit by a rash of terrorist bombings last winter, admitted that "ironclad" security is a myth..$^{34}$ However, much of the panic and ineffectual action which can occur when a bomb threat is received may be eliminated by the formulation of a written policy on search and evacuation procedures. Staff members should be given set responsibilities; joint planning with the campus security police and the department of buildings is essential. Emergency phone numbers including the Army bomb disposal unit should be readily available. To avoid undue tragedy, the staff should be emphatically instructed never to disturb a suspicious object, but rather to report it to the authorities according to predetermined procedures. ${ }^{35}$

Other written policies and information must be made available before violence strikes. For example, the administration manual circulated to the staff of the library at Berkeley includes tear gas instructions. ${ }^{36}$ Barbara Anderson warns that the lack of a written policy 
on riots at San Francisco State was seriously debilitating:

We had no guidelines ... other than an official statement regarding the closing of buildings during emergencies which placed the responsibility in the hands of the college librarian "when the danger is imminent." Just when is imminent danger really imminent? What if a bomb is detonated in the neighboring building? What if there is a fire reported in a building across the campus quad? These things happen, and they did happen to us. ${ }^{37}$

She concludes that internal morale becomes another problem during a prolonged student strike. Questions of ethics should be discussed well in advance and formulated into written policy to provide the solidarity among personnel that is necessary to assure protection of the library during times of crisis.

During riot conditions, exit security procedures might well be reversed into entrance checks. All bags and briefcases carried into the building should be examined. Happily, since a bomb is not as easily concealed as a book, the results of searches should be relatively effective if guards are insistent and thorough. Stack security and security of other areas to which free access is normally provided, including the restrooms, should be limited. Though it may seem unprofessional to assign a librarian to security detail, it may be necessary. Service to clientele is important, but in crisis times protecting the library is even more important. If lax security leads to irreparable damage to the library, it may be impossible to provide any service at all.

Other preventive measures should be taken well in advance. The most valuable materials in the collection should be isolated and microfilmed. In particular, the Library Technology Project recommends protective facilities, such as a vaultlike structure, for the card cata$\log { }^{38}$ However, this may be impractical for most institutions. Practice card catalog drills and microfilming may be a more realistic solution. For example, the University of Washington microfilmed the entire contents of its catalog in 20 days at a total cost of $\$ 2,930$. Costs of microfilming additions are estimated to be about $\$ 7$ a month. ${ }^{39}$

It is unfortunate that the two major texts on planning academic library building were written before the advent of major campus disorders and do not offer too much information on the question of security problems. Ralph E. Ellsworth has only a brief comment on the difficulty of fireproofing modern steel bookstacks. He cites the fire test performed at Norwood, Massachusetts for the New York Public Library. He also notes that traditional multitier bookstacks are equally bad, citing the disastrous Jewish Theological Seminary fire. Even modular buildings with fireproof columns, such as Wayne State University, are not really fireproof. Ellsworth concludes, "A combination of a good fire detection system with a generous supply of $\mathrm{CO}_{2}$ extinguishers would appear to be the best solution to the problem. ${ }^{40}$

Keyes D. Metcalf gives more extensive advice on fire alarms, fire doors, and fire extinguishers, recommending the American Library Association's Protecting the Library and Its Resources for further details on planning, fire defense, and insurance needs. Unfortunately, he does not provide much guidance on how to design more secure structures. ${ }^{41}$ Librarians would do well to consider the experience of businesses that have protected valuable resources in areas prone to riot by designing buildings like fortresses that have few or no exterior windows. ${ }^{42}$ Natural light may be provided by windows facing an interior court, and they should always be made of special vandal-resistant materials. The library at Post College in 
Brookville, New York, used polyester resin fiber glass panels that resist both fire and breakage. Plexiglas acrylic plastic can reduce window breakage by as much as 90 percent. $^{43}$ Vandal alarm systems may also help curtail attacks while the library is closed. ${ }^{44}$

The major problem is that little has been written on what to do after a fire or incendiary bombing has occurred. Because a library contains valuable office equipment and books, care must be taken to secure the premises immediately to prevent looting. Further, if the building is not totally damaged, water vacuums and fire-retardant paint can be used to put the library back in semiworking order. ${ }^{45}$ More research on salvaging materials is needed. In general, the worst effect of a fire is the water damage to books.

A brief recount of the Jewish Theological Seminary fire will not only demonstrate the many problems of reclaiming the collection but also show the feasibility of salvaging materials. ${ }^{46}$ The April 18, 1966 fire destroyed 70,000 volumes and left about 150,000 completely waterlogged volumes in seven stacks. The day after the fire, volunteers began to remove the salvageable books and started experimenting with drying methods. Quick-dry freezing and baking in microwave ovens gave excellent results, but proved much too time-consuming since only 150 books a week could be processed. The final solution was to put paper towels between each pair of pages. The effort involved was enormous:

It involved an estimated two-and-a-half million separate operations, as volunteers patiently placed the sheets of toweling between the wet pages, pressed the book shut, and removed the paper twenty-four hours later. ... The final treatment ... was the application of an alcohol rub whenever residual dampness threatened to create mold.
A few burned books were restored by photographing them with ultraviolet light on xerographic paper, but this method was extremely expensive.

A final thought on the prevention of student attacks on libraries was given by John Berry, III, then assistant editor of the Library Journal. According to Berry, the students, particularly undergraduates, have legitimate complaints against the library since they are often treated as "second-class library citizens" with the major attention going to the faculty. Berry suggests quelling student hostility by giving the students more freedom and responsibility, as well as trying to achieve "Branscomb's 20-year-old dream" by trying to find "a replacement, both pedagogic and bibliographic, for the reserve book." ${ }^{77}$ Ensuring library security by considering student motivation is laudable yet impractical, because the solutions suggested are prohibitively expensive. Moreover, it is not really certain that the attacks on the library are really due to student dissatisfaction with the library itself. According to Anderson, the attacks on the library at San Francisco State were not "anti-library" but "anti-Establishment." 48

In conclusion, student violence is still a serious problem confronting American college and university librarians. Even the threat of violence can create a serious financial drain on the library. Destruction of unique special collections is not even measurable in financial terms, because such collections cannot be replaced. This violence is extremely complex and inadequately researched. Student violence is an especially fascinating topic, but without extensive, well-planned investigation this major security problem cannot be effectively solved in the near future.

\section{REFERENCES}

1. "Campus Revolts Over?," U.S. News 
and World Report 68:53 (February 16, 1970).

2. Ibid., p.55.

3. The New York Times (January 3, 1970), p.6.

4. "Campus Revolts," p.55.

5. "Campus Revolt: No End in Sight," U.S. News and World Report 68:82 (April 13, 1970).

6. "The House on 11th Street," Newsweek 75:30 (March 23, 1970).

7. The New York Times (March 29, 1970), p.1.

8. "The Price of Violence," Time 95:81 (June 1, 1970).

9. Alan E. Bayer and Alexander W. Astin, "Violence and Disruption on the U.S. Campus, 1968-69," Educational Record 50:338 (Fall 1969).

10. Roger Rapoport and Laurence J. Kirshbaum, Is the Library Burning? (New York: Random House, 1969).

11. "Wayne State Library Struck by Arsonist," Library Journal 92:2990-92 (September 15, 1967).

12. "Columbia University Strike," Library Journal 93:2191 (June 1, 1968).

13. "Indiana University Library Suffers Fire Loss," Library Occurrent 23:58 (May 1969).

14. "Indiana University Library Fire," $A B$ Bookman's Weekly 43:884 (March 17, 1969).

15. "Indiana University Library Burns Again,” Library Journal 94:2384 (June $15,1969)$.

16. "Blacks Rough Up Books at Brandeis Library," Library Journal 94:704 (February 15,1969 ).

17. "Blacks Hit Library at Queens College," Library Journal 94:481-2 (February 1,1969 ).

18. "U. of Illinois Catalog Damaged by Vandals," Library Journal 94:1086 (March 15, 1969).

19. Library Journal 94:1539 (April 1, 1969).

20. "Vandalism and Harassment at Beloit," Library Journal 94:1566 (April 1, 1969).

21. The New York Times (April 18, 1969), p.29.

22. "Victor Hugo on the Burning of a Li- brary," Wilson Library Bulletin 43:981 (June, 1969).

23. "University of Washington Badly Damaged by Bomb," Library Journal 94: 3395 (October 1, 1969).

24. Barbara Anderson, "Ordeal at San Francisco State College," Library Journal 95:1275-80 (April 1, 1970).

25. The New York Times (February 22, 1970), p.1; (March 14, 1970), p.18.

26. Los Angeles Times (March 14, 1970), p. 25 .

27. "Berkeley Library Damaged by Fire," The New York Times (March 10, 1970), p.23.

28. "Education: Campus Communiqué," Time 95:44 (April 20, 1970); The New York Times (April 25, 1970), p.35.

29. "SUNY-Buffalo L.S. Students Fight to Save School," Library Journal 95:1418 (April 15, 1970).

30. "Univ. of Washington Rioting Rocks Campus Libraries," Library Journal 95: 1686 (May 1, 1970).

31. The New York Times (April 28, 1970), p.1.

32. "New York Public Hit by Bombs," Library Journal 95:107 (January 15, 1970).

33. Bayer and Astin, "Violence and Disruption," p.340.

34. Wall Street Journal (March 13, 1970), p.1.

35. J. C. Gardner, "How to Prepare for a Bomb Scare," American School and University 43:68 (February 1970).

36. "Tear Gas Instructions Given Berkeley Librarians," Library Journal 94:4090 (November 15, 1969).

37. Anderson, "Ordeal," p.1280.

38. Library Technology Project, Protecting the Library and Its Resources (Chicago: American Library Association, 1963), p.37-8.

39. "Apprehensive Librarians Microfilm Catalog," Library Journal 94:2384-6 (June 15, 1969).

40. Ralph E. Ellsworth, Planning the College and University Library Building, 2d ed. (Boulder, Colorado: Pruett Press, Inc., 1968), p.93.

41. Keyes D. Metcalf, Planning Academic and Research Library Buildings (New 